\title{
OCCUPATIONAL STRESS, ILL HEALTH AND ORGANISATIONAL COMMITMENT OF EMPLOYEES AT A UNIVERSITY OF TECHNOLOGY
}

Authors:

Joshua P. Viljoen ${ }^{1}$

Sebastiaan Rothmann ${ }^{2}$

\author{
Affiliations: \\ ${ }^{1}$ School of Behavioural \\ Sciences, North-West \\ University, South Africa \\ ${ }^{2}$ Department of Human \\ Sciences, University of \\ Namibia, Namibia
}

Correspondence to:

Sebastiaan Rothmann

e-mail:

ian@ianrothmann.com

\section{Postal address:}

PO Box 8660,

Swakopmund,

Namibia, 9000

\section{Keywords:}

occupational stress;

organisational commitment; ill health, work overload; work-life balance

\section{Dates:}

Received: 12 July 2008

Accepted: 23 Jan. 2009

Published: 30 Apr. 2009

How to cite this article: Viljoen, J.P., \& Rothmann, S. (2009). Occupational stress, ill health and organisational commitment of employees at a university of technology. SA Journal of Industrial Psychology/SA Tydskrif vir Bedryfsielkunde, 35(1), Art. \#730, 11 pages.

DOI: 10.4102/sajip.v35i1.730

This article is available at: http://www.sajip.co.za

(c) 2009. The Authors. Licensee: OpenJournals Publishing. This work is licensed under the Creative Commons Attribution License.

\section{INTRODUCTION}

Since 2002, the South African higher education system has undergone a complex restructuring process involving the merger of higher education institutions. Consequences such as financial predicaments, increased demands, insecurity and rapid changes are unavoidable and cause increasing emotional turmoil and stress (Barkhuizen \& Rothmann, 2008; Clarke \& Koonce, 1995; Hellriegel, Slocum \& Woodman, 2001; Mestry, 1999). Seijts and O'Farrell (2003) note that poor staff morale and staff insecurities due to possible retrenchments, redundancies and redeployment usually accompany the merger of higher education institutions.

The restructuring of higher education institutions is not a uniquely South African phenomenon. Universities and colleges of education have undergone restructuring in many other countries, such as Canada, Australia, Russia, China and the United States of America, and in Great Britain (Blackmore, 2002; Curri, 2002; Finkelstein, 2003; Gumport, 2000; Mok, 2003; Wood \& Meek, 2002). Several reasons have been suggested as to why higher education institutions had no choice but to undergo a process of restructuring, namely, governments' diminishing ability to subsidise education; restructuring of global capitalism and the emergence of neo-liberal macro-economics (Kraak, 2004; Manicas, 1998; Mok, 2003; Woodard, 1997); technological advances that have increased the demand for distance teaching (Mok, 2003); and socio-political changes in countries that have triggered the restructuring of their government institutions, including higher education (Finkelstein, 2003; Mok, 2003).

In South Africa, the successful transition from the 'current' to the 'envisaged' new system is of extreme importance as it will determine to a large extent the future success of high-level human resource development in the country. Khosa (1996) accentuates this statement in acknowledging that stable and productive support systems in terms of higher education and training are of vital importance to any country in order to ensure sustainable economic, social and political reconstruction and development.

Changes in higher education institutions affect staff in numerous ways, as proven in a 1996 survey of the academic profession, using data from 14 countries worldwide. Results from the survey show that significant changes have taken place in higher education (Altbach, 1996). Some of these changes include demands for greater accountability, value for money, efficiency and quality, and an increase in remote and autocratic management styles (AUT, 1990). There has also been a gradual erosion in pay and job security and, with the abolition of tenure in the 1980s, an increasing number of staff have been appointed on fixed-term contracts. Moreover, these changes in conditions are now being reflected in levels of job satisfaction and commitment. For example, a recent study of levels of job satisfaction experienced by academics from Australia, Germany, Hong Kong, Israel, Mexico, Sweden and the UK revealed that fewer than $50 \%$ of British academics were generally satisfied with their jobs (Lacy \& Sheehan, 1997).

Apart from the kinds of stress related to academic work in other contexts, South African academics have had to face stresses associated with the radical transformation of the South African society and the demand that education itself become transformed while making a contribution to the wider transformation of society. Seldin (1991, p. 14) explains that 'levels of stress of staff on campuses have risen appreciably in recent years and are likely to get worse'. This is relevant for both academic and support staff who contribute to daily operations and the success of a higher education institution (see Barkhuizen \& Rothmann, 2008; Mostert, Rothmann, Mostert \& Nell, 2008; Rothmann \& Essenko, 2007).

\section{Occupational stress}

According to Cooper and Dewe (2004, p. 1), the term stress may have been derived from the Latin word 'strictere', which literally means 'to draw tight.' The literature offers various definitions of this phenomenon. Schafer (2000, p. 6) defines stress as 'arousal of mind and body in response to demands made on them'. Varca (1999) defines stress as a gap between environmental demands and personal resources to meet those demands. Anderson, Litzenberger and Placas (2002) define stress as 'the response of an individual to the self-perceived imbalance between the demands of the situation presented, and 
the resources one has at one's disposal to respond successfully.' All of the above definitions reflect on the perceived relationship between demands on individuals and their ability to cope with those demands. In other words, the stressfulness of the situation will depend on people's assessment and perception of the difference between the demands of the situation and their ability to meet those demands. This correlation between stress and well-being is emphasised by Jamal (1999).

Occupational stress has the same typical characteristics, with the exception that it appears specifically within the parameters of the work environment, is caused by work-related factors and also has consequences for the work situation (Rothmann \& Cooper, 2008). It implies that a person cannot effectively handle work-related demands, such as work overload, role conflict in the workplace and poor working conditions. Mention is made of a 'mismatch' between the demands made upon an individual and his/her ability to cope with them (Weinberg \& Cooper, 2007).

The level of stress an individual experiences in his or her organisational context, and the extent to which adverse effects such as psychological and other strains occur, depend on how effectively he or she copes with stressful organisational situations (Bhagat, Ford, Driscoll, Frey, Babakus \& Mahanyele, 2001). Research on stress has indicated that people working in the helping professions where they are dealing with people, especially educators, are particularly prone to stress (Barkhuizen \& Rothmann, 2008; Kyriacau, 2001). It is widely accepted that stress has a major influence on a professional person's performance and extensive research has been done in this regard, for example, among educators, nurses and managers (Houghton, 2001, p. 706). The presence of stress at work is almost inevitable in many occupations. However, individual differences account for a wide range of reactions to stress; a task viewed as challenging by one person may produce high levels of anxiety in another.

Conditions that tend to cause stress are called stressors (Newstrom \& Davis, 2002). The term stressor(s) is used to refer to the demands made on a person (Jones \& Bright, 2001), which act as a stimulus for evoking a response, such as emotions of anger, anxiety and stress (Abouserie, 1996; Rothmann \& Cooper, 2008). An external stressor (e.g. one's job, family or friends) or an internal stressor (e.g. ambition, competitiveness and frustration) can activate stress. Although even a single stressor may cause major stress, usually stressors combine to put pressure on an employee in a variety of ways until stress develops (Newstrom \& Davis, 2002).

One of the latest and most widely-accepted models to assess and explain the dynamics of occupational stress is the ASSET (An Organizational Stress Screening Tool) model, developed by Cartwright and Cooper (2002). The ASSET model is a measurement instrument based on a conceptual framework that measures an employee's potential exposure to stress with reference to a number of occupational stressors.

According to the ASSET model by Cartwright and Cooper (2002), there are eight sources that contribute to the experience of occupational stress and levels of commitment, namely, Work Relationships, Work-Life Balance, Overload, Job Security, Control, Resources and Communication, Pay and Benefits and Job Aspects. It is, however, evident from the literature that most of these stressors have a multi-dimensional nature and any one, or a combination thereof, can lead to the experience of stress. Newstrom and Davis (2002) further state that almost any job condition can cause stress, depending on the employee's reaction to the condition.

Relationships with colleagues and/or superiors can be either positive (helping individuals cope with stress) or negative (creating stress). Studies found that strained work relationships and interpersonal conflict at work predicted physiciandiagnosed psychiatric morbidity, mental instability and stress (neuroticism, hostility, life stress, low self-assurance) (Romanov, Appelberg, Honkasalo \& Koskenvuo, 1996). A work environment characterised by conflict in relationships or poor social support seems to predict the experience of stress. Conversely, good relationships at work can help individuals to cope with stress (Industrial Society, 2001).

Balancing the demands of an occupation with family and personal life, namely, work-life balance, is a complex and thoroughly researched phenomenon. Studies have identified the contribution of factors linked to family, social networks, and individual characteristics to the development of stress. It has been found that psychological distress is associated with marital status (Shirom, Westman \& Melamed, 1999), parental status (Pugliesi, 1999), strained relations with spouses, children, friends, and neighbours (Voydanoff \& Donnelly, 1999), the economic situation of the household (McDonough, 2000), weak social support (Van der Doef, Maes \& Diekstra, 2000) and the need to balance work and family life (Grzywacz, 2000; Voydanoff \& Donnelly, 1999). With regard to social networks outside work, findings reveal that having a variety of sources of social support and actively participating in such networks tend to lower levels of distress (Bourbonnais, Comeau \& Vezina, 1999).

The relationship between workload or overload and stress is well documented (Faragher, Cooper \& Cartwright, 2004). Some of the factors contributing to this ambivalent relationship are physical demands related to the environment and individual effort (Demerouti, Bakker, Nachreiner \& Schaufeli, 2000), psychological and emotional demands caused by workload, pace of work, conflicting requests, role ambiguity (Demerouti et al., 2000; Van der Doef et al., 2000), and irregular schedules and long hours (Bourbonnais et al., 1999; Spurgeon, Harrington \& Cooper, 1997).

The potential for the development of stress associated with job security (the fear of losing one's job, changes in the workplace or redundancy) have been listed by various researchers (Bourbonnais et al., 1999; McDonough, 2000). O'Driscoll and Cooper (1996) mention that the fear associated with the prospect of losing a job is one of the biggest sources of stress in employees.

The amount of authority an individual has in making decisions regarding the way work is organised and performed refers to control. This is confirmed by De Jonge, Reuvers, Houtman, Bongers and Kompier (2000) and Van der Doef et al. (2000), who add that control goes hand in hand with authority and levels of utilisation. Makin, Cooper and Cox (2003) explain that individuals who perceive that they can control their environment are less likely to suffer stress than those who do not. Glass and McKnight (1996) found that the inability to exercise control in the workplace ('uncontrollability') contributes to negative psychological states especially when there is a discrepancy between career aspirations and occupational achievement that is, if there is career dissatisfaction.

Employees need adequate resources (training, equipment) and effectivecommunicationinorder toperform theirjobs effectively. According to Daniels and Guppy (1994), open communication in organisations can decrease levels of stress experienced by employees, but organisational communication will only be effective if it provides accurate information, thereby increasing the predictability of the working environment. A deficiency in these workplace stressors have been found to be associated with increased levels of stress (Pilkington, Mulholland \& Cowie, 2001; Industrial Society, 2001). Furthermore, poor communication was found to be the third highest rated stressor in the British Industrial Society report. In a study undertaken by Tytherleigh (2003) it was found that work relationships, job 
security, resources and communication caused the highest levels of strain for educators.

Demerouti et al. (2000) and Tepper (2000) found that levels of stress experienced by employees are also related to monetary rewards (pay and benefits). Shirom et al. (1999) broadened this view by explaining that there is also a link between levels of stress and performance pay.

There are also a number of job aspects that frequently cause stress. When dealing with stress, it is important to accurately identify the stressors in the educator's job that may lead to stress, job dissatisfaction and low organisational commitment. Van Zyl and Buitendach (2004) highlighted a list of stressors in the education profession, including lack of fit between person and environment, classroom, supervision, time pressures, learner discipline, system of promotion, salary, lack of decision-making, role conflict, role ambiguity, role overload, role insufficiency, responsibility towards others, contact overload, attitudes of parents and community, frequent clashes with superiors, redundancy, retrenchments and cutbacks and educator strikes as such. Intrinsic factors identified in the study of Wevers and Steyn (2002) among educators were learneroriented factors, achievement, acknowledgement and praise, positive work impact, autonomy, salaries, promotion, job security, fair treatment, professional respect, lack of support services, working hours, disciplinary problems and lack of community commitment. Johansson (1989) and Shirom et al. (1999) also list repetitive work with little or no variety and change as a factor.

According to Kinman (2001), research has demonstrated that stressors can have a wide-ranging negative impact on the individual. Strain refers to reactions to the conditions of stress (Dollard, Winefield \& Winefield, 2003), and is observable at a cognitive level (a decline in the quality of decision making, lower levels of creativity, impaired memory); behavioural level (absenteeism, poor time management, substance abuse, irritability); physical level (headaches, digestive disorders, cardiovascular disease) and psychological level (depression, anxiety, low self-esteem) (Rothmann \& Cooper, 2008).

Quick, Nelson and Hurrell (1997) noted that while stress and strain are features of organisational life, these concepts tend to be ambiguously defined. Despite the ambiguity, stress and strain remain a matter of serious concern to medical and organisational professionals. The concern is for two reasons: the first is economic, as mismanaged stress can be costly to organisations since it leads to lost productivity and increased health care costs. The second is humanitarian, as it is not desirable to overstress individuals. Leong, Furnham and Cooper (1996) stated that stress resulting from work is a major problem, both for individuals within an organisation and for organisations themselves. For this reason, it is argued that it is in the organisation's best interest to intervene and minimise the amount of stress that is caused by continuous organisational change in particular (Mack, Nelson \& Quick, 1998).

\section{Commitment}

According to the ASSET model, the above-mentioned sources of occupational stress affect the commitment relationship between the organisation and the individual. Organisational commitment is defined as the employee's feelings of obligation to stay with the organisation: feelings resulting from the internalisation of normative pressures exerted on an individual prior to entry or following entry (Allen \& Meyer, 1990). Mowday, Porter and Steers (1982) define organisational commitment as the relative strength of an individual's identification with and involvement in a particular organisation. Organisational commitment is an individual's orientation towards the organisation in terms of loyalty, identification and involvement (Robbins, 1998). Organisational commitment is defined as the extent to which employees identify with their organisation and managerial goals (Chow, 1994; Kreitner \& Kinicki, 1995), show a willingness to invest effort, participate in decision-making and internalise organisational values (Chow, 1994).

Commitment of the organisation to the employee (organisational commitment) refers to employees' expectations to be trusted and respected and feeling that it is worth 'going the extra mile' for the organisation. Commitment of the employee to the organisation (individual commitment), on the other hand, implies expectations of the organisation that its employees will do their job to the best of their ability and that they will be loyal and dedicated to the organisation (Cartwright \& Cooper, 2002).

According to Meyerand Allen(1991), organisational commitment can take three distinct forms, namely affective, continuance and normative commitment. Affective commitment refers to identification with, involvement in, and emotional attachment to the organisation, in the sense that employees with strong affective commitment remain with the organisation because they want to do so. Continuance commitment refers to commitment based on employees' recognition of the costs associated with leaving the organisation. Thus, employees with strong continuance commitment remain with the organisation because they have to do so, either because of low perceived alternatives or because of high personal sacrifice associated with leaving the organisation. Normative commitment refers to commitment based on a sense of obligation to the organisation. Those with strong normative commitment remain with the organisation because they feel they ought to do so. It could be argued that employees with strong affective commitment would be more willing to accept change, provided that such a change is not altering the basic values and goals of the organisation, and is seen as beneficial to the organisation, since organisational commitment reflects a belief in the values and goals of the organisation.

Within the structure of the ASSET model, commitment measures an effect of stress, reflecting the non-economic reciprocal obligations which extend between employer and employee (Cartwright \& Cooper, 2002). However, issues other than workplace stress may affect employees' level of commitment. For example, industrial action such as a threatened union strike may affect employees' commitment to their organisation.

Despite the plethora of studies on organisational commitment and its nature, antecedents, consequences and collates, the construct remains ill-defined and ill-conceptualised (Suliman \& Iles, 2000b). According to Suliman and Iles (2000a), the following are important aspects of organisational commitment: it improves employees' performance, that is, committed employees are assumed to be motivated to work hard and put in more effort than less committed employees; it fosters better superior-subordinate relationships; it enhances organisational development, growth and survival; it improves the work environment; it negatively influences withdrawal behaviour, such as turnover, tardiness and absenteeism; and it has a positive impact on employees' readiness to innovate and create. Commitment is usually stronger among longerterm employees, those who have experienced personal success in the organisation, and those working within a committed employee group. Organisationally committed employees will usually have good attendance records, demonstrate a willing adherence to company policies, and have lower turnover rates (Newstrom \& Davis, 2002).

\section{Ill health}

There is ample evidence that occupational stress has an impact on workers' mental and physical well-being (Kahn \& Byosiere, 1992). According to Siu (2002) and Winefield, Gillespie, Stough, Dua and Hapuararchchi (2002), there is significant evidence to suggest that chronic and high levels of occupational stress, left 
TABLE 1

Characteristics of participants

\begin{tabular}{|c|c|c|c|}
\hline ITEM & CATEGORY & FREQUENCY & PERCENTAGE \\
\hline \multirow[t]{2}{*}{ Employment category } & Academic & 132 & 37.4 \\
\hline & Support & 221 & 62.6 \\
\hline \multirow[t]{2}{*}{ Gender } & Female & 221 & 63.3 \\
\hline & Male & 128 & 36.7 \\
\hline \multirow[t]{5}{*}{ Marital status } & Single & 61 & 17.4 \\
\hline & Engaged/in relationship & 20 & 5.7 \\
\hline & Married & 231 & 65.8 \\
\hline & Divorced & 32 & 9.1 \\
\hline & Widow/er & 7 & 2.0 \\
\hline \multirow[t]{3}{*}{ Language } & Afrikaans & 244 & 69.9 \\
\hline & English & 42 & 12.0 \\
\hline & Other & 43 & 18.1 \\
\hline \multirow[t]{4}{*}{ Age distribution } & $20-30$ & 73 & 21.7 \\
\hline & $31-40$ & 118 & 35.0 \\
\hline & $41-50$ & 94 & 27.9 \\
\hline & $51+$ & 52 & 15.4 \\
\hline \multirow[t]{5}{*}{ Education } & Grade 12 or lower & 91 & 26.2 \\
\hline & 3 year qualification & 75 & 21.6 \\
\hline & 4 year qualification & 102 & 29.4 \\
\hline & Master's & 63 & 18.2 \\
\hline & Doctoral & 16 & 4.6 \\
\hline \multirow[t]{4}{*}{ Years of service } & $0-2$ years & 51 & 15.4 \\
\hline & $3-5$ years & 80 & 24.1 \\
\hline & $6-10$ years & 109 & 32.8 \\
\hline & 11 years + & 92 & 27.7 \\
\hline \multirow[t]{3}{*}{ Opportunity for promotion } & none & 115 & 40.2 \\
\hline & 1 & 120 & 42.0 \\
\hline & $2+$ & 51 & 17.7 \\
\hline \multirow[t]{2}{*}{ Smokes } & Yes & 67 & 19.3 \\
\hline & No & 281 & 80.7 \\
\hline \multirow[t]{2}{*}{ Drinks alcohol } & Yes & 232 & 66.9 \\
\hline & No & 115 & 33.1 \\
\hline
\end{tabular}

unchecked, are related to mental and physical well-being, job dissatisfaction, absenteeism, stress-related injuries, turnover, and intention to quit. They have shown significant correlations between higher levels of psychological strain and incidences of self-reported stress-related health symptoms, such as sleeping difficulties, headaches, and viral and cold infections. Furthermore, these symptoms significantly associate with stress-related medical conditions reported by staff members, such as migraines, hypertension and coronary heart disease. Other possible psychological problems include burnout, alcohol abuse, unexplained physical symptoms, absenteeism, chronic fatigue and accidents, sick building syndrome and repetitive strain injury (Hothopf \& Wesseley, 1997). Lu (1999) estimates that occupational stress causes half of absenteeism, $40 \%$ of turnover and $5 \%$ of total lost productivity.

Psychological health refers to clinical symptoms indicative of stress-induced mental ill-health (for example, constant tiredness and irritability), while physical health refers to physical symptoms often associated with stress (for example, insomnia/sleep loss and headaches.) If untreated, psychological distress can cause more serious reversible health problems (psychosomatic illnesses, arterial hypertension, severe depression, alcoholism), and over time, it can also lead to irreversible damage (permanent disability, premature deaths, suicide, cardiovascular and neuropsychiatric diseases). Overall, the presence of psychological distress is a sign that something is going wrong in the individual psyche (Marchand, Demers, Durand \& Simard, 2003). The ASSET model (Cartwright \& Cooper, 2002) considers poor employee health to be a potential indicator of stress. However, poor health is not necessarily a direct consequence of workplace stress. Individuals may be unwell because of an organic susceptibility to illness or due to leading an unhealthy lifestyle. In addition, stress-related illnesses may be caused by the existence of stressors outside the workplace such as the break-up of a relationship or a recent bereavement.

It seems that stress and related health problems result in great costs within the organisational context. In this regard, Everley and Fieldman state:

This relentless upward spiral of health benefit costs is taking its toll throughout industry. Each year corporations are forced to allocate a large share of their operating expenses just to provide employee health benefits, resulting in higher consumer prices or lower profits, or both.

(Everley \& Fieldman, 1991, p.6)

The direct costs of stress and the resulting poor performance manifest in a number of ways. Numerous research studies (Carstens, 1989; Ivancevich \& Mattheson 1996; Jacobs, 2001; Quick et al., 1992) have shown that individuals experiencing stress make errors, are absent from work more often, must be replaced more frequently and are involved in work accidents and strikes, as well as work slowdowns. In this regard, Pillay and Claase-Schutte (2003) mention that South Africa loses billions of rand each year as a result of diminished productivity, absenteeism, medical fees and high employee turnover.

Indirect costs include the question of the cost of lost opportunities. Researchers demonstrated that stressed employees are less creative, less effective decision-makers and inadequate communicators (Schaufeli, Maslach \& Marek, 1993). Other indirect costs due to high stress can include a lack of confidence in management and colleagues, poor labour relations, and low morale.

\section{Aim of the study}

The aim of this study was to investigate the relationship between perceived organisational stressors and staff's levels of commitment and health. 
The following hypotheses can be formulated from the above discussion:

H1: Occupational stressors predict physical and psychological ill health of staff.

H2: Occupational stressors predict low organisational and individual commitment of staff.

\section{Research approach}

\section{RESEARCH DESIGN}

A cross-sectional survey design targeting all permanent employees of the higher education institution was used. Questionnaires were used to gather data in a field survey. This design is suitable to describe the relationships between variables.

\section{Research method}

\section{Participants}

The study population consisted of support staff $(\mathrm{N}=1084)$ and academic staff $(\mathrm{N}=529)$ of a higher education institution in South Africa. A total of 1613 questionnaires were distributed across six campuses. All available staff were included in the survey. A total of 353 questionnaires were completed and returned. This included responses from 132 academic and 221 support staff members. The total response rate was $21.88 \%$ ( $24.95 \%$ for academic staff and $10.6 \%$ for support staff). The characteristics of the participants are shown in Table 1.

Females constituted $63.3 \%$ and males $36.7 \%$ of the participants. The majority of the participants $(65.8 \%)$ were married. Different language groups were included in the study. A total of $69.9 \%$ of the participants were Afrikaans speaking, $12 \%$ were English speaking and $18.1 \%$ spoke indigenous languages.

The age distribution pointed to a reasonably young workforce with only $15.4 \%$ older than 50 years. In total, $22.8 \%$ of the population obtained a Master's (or related) qualification and/ or a higher qualification. A total of $60.5 \%$ of the participants had been in service at the institution for more than six years. Furthermore, $40.2 \%$ reported that they had no opportunity to be promoted during their years of service. A total of $80.7 \%$ of the respondents indicated that they do not smoke, and $66.9 \%$ admitted to drinking alcohol.

\section{Measuring instruments}

The following measuring instruments were used in the empirical study:

An Organizational Stress Screening Tool (ASSET) developed by Cartwright and Cooper (2002) as a screening tool to help organisations assess the risk of occupational stress in their workforce. It measures potential exposure to stress in respect of a range of common workplace stressors. It also provides important information on current levels of physical health, psychological well-being and organisational commitment. The ASSET is divided into three questionnaires. The first questionnaire (37 items) measures the individual's perception of his or her job while the second questionnaire (nine items) measures the individual's attitude to his or her organisation. Both of these were scored on a six-point scale ranging from 1 (strongly disagree) to 6 (strongly agree). The third questionnaire (19 items) focuses on the individual's health and was scored on a four-point scale ranging from 1 (never) to 4 (often).

The ASSET has an established set of norms from a database of responses from 20000 workers in public and private sector organisations in the United Kingdom. It presents scores in sten (standardised ten) format. A sten is a standardised score based on a scale of 1 to 10 , with a mean of 5.5 and a standard deviation of 2 . The sten system enables meaningful comparison to the norm group. Most people (68\%) score between sten 3 and sten 8. Scores that fall further from the mean (either in the high or the low direction) are considered to be more extreme. About

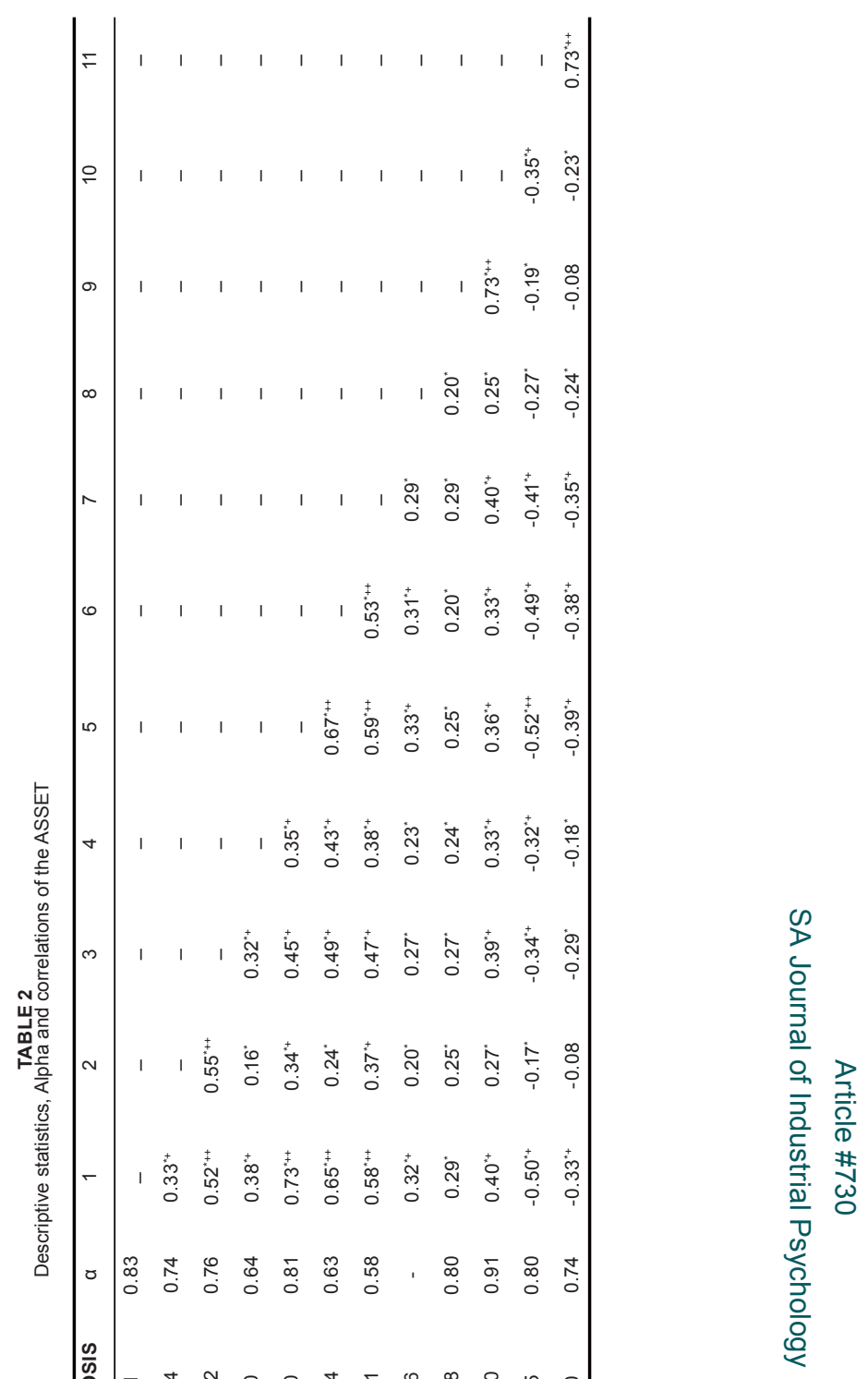


TABLE 3

Standard multiple regression analysis with physical and psychological ill health as dependent variables

\begin{tabular}{|c|c|c|c|c|c|c|c|c|c|c|}
\hline \multirow[t]{2}{*}{$\begin{array}{l}\text { DEPENDENT } \\
\text { VARIABLE }\end{array}$} & & \multicolumn{2}{|c|}{$\begin{array}{l}\text { UNSTANDARDISED } \\
\text { COEFFICIENTS }\end{array}$} & \multirow{2}{*}{$\begin{array}{c}\begin{array}{c}\text { STANDARDISED } \\
\text { COEFFICIENTS }\end{array} \\
\text { Beta }\end{array}$} & \multirow[t]{2}{*}{$t$} & \multirow[t]{2}{*}{$p$} & \multirow[t]{2}{*}{$F$} & \multirow[t]{2}{*}{$R$} & \multirow[t]{2}{*}{$R^{2}$} & \multirow[t]{2}{*}{$\Delta R^{2}$} \\
\hline & & B & SE & & & & & & & \\
\hline \multirow[t]{10}{*}{ Physical ill health } & & & & & & & $7.31^{*}$ & 0.38 & 0.15 & 0.13 \\
\hline & (Constant) & 7.13 & 0.95 & & 7.55 & 0.00 & & & & \\
\hline & Work Relations & 0.08 & 0.05 & 0.13 & 1.54 & 0.12 & & & & \\
\hline & Work-Life Balance & 0.11 & 0.06 & 0.12 & 1.87 & 0.06 & & & & \\
\hline & Overload & 0.06 & 0.08 & 0.06 & 0.80 & 0.42 & & & & \\
\hline & Job Security & 0.14 & 0.06 & 0.12 & 2.13 & $0.03^{*}$ & & & & \\
\hline & Control & 0.02 & 0.08 & 0.02 & 0.24 & 0.81 & & & & \\
\hline & Resources & -0.10 & 0.09 & -0.08 & -1.06 & 0.29 & & & & \\
\hline & Job Aspects & 0.08 & 0.05 & 0.11 & 1.62 & 0.11 & & & & \\
\hline & Pay & 0.21 & 0.14 & 0.08 & 1.52 & 0.13 & & & & \\
\hline Psychological & & & & & & & $14.89^{*}$ & 0.51 & 0.26 & 0.24 \\
\hline \multirow[t]{9}{*}{ ill health } & (Constant) & 6.90 & 1.40 & & 4.94 & 0.00 & & & & \\
\hline & Work Relations & 0.11 & 0.08 & 0.11 & 1.48 & 0.14 & & & & \\
\hline & Work-Life Balance & 0.06 & 0.09 & 0.04 & 0.69 & 0.49 & & & & \\
\hline & Overload & 0.29 & 0.11 & 0.17 & 2.55 & $0.01^{*}$ & & & & \\
\hline & Job Security & 0.27 & 0.09 & 0.15 & 2.85 & $0.01^{*}$ & & & & \\
\hline & Control & 0.06 & 0.12 & 0.04 & 0.46 & 0.64 & & & & \\
\hline & Resources & -0.04 & 0.13 & -0.02 & -0.33 & 0.74 & & & & \\
\hline & Job Aspects & 0.19 & 0.08 & 0.15 & 2.47 & $0.01^{*}$ & & & & \\
\hline & Pay & 0.33 & 0.21 & 0.08 & 1.60 & 0.11 & & & & \\
\hline
\end{tabular}

$* p<0.05$

TABLE 4

Standard multiple regression analysis with organisational and individual commitment as dependent variables

\begin{tabular}{|c|c|c|c|c|c|c|c|c|c|c|}
\hline \multirow[t]{2}{*}{$\begin{array}{l}\text { DEPENDENT } \\
\text { VARIABLE }\end{array}$} & & \multicolumn{2}{|c|}{$\begin{array}{l}\text { UNSTANDARDISED } \\
\text { COEFFICIENTS } \\
\end{array}$} & \multirow{2}{*}{$\begin{array}{l}\text { STANDARDISED } \\
\text { COEFFICIENTS } \\
\text { Beta }\end{array}$} & \multirow[t]{2}{*}{$t$} & \multirow[t]{2}{*}{$p$} & \multirow[t]{2}{*}{$F$} & \multirow[t]{2}{*}{$R$} & \multirow[t]{2}{*}{$R^{2}$} & \multirow[t]{2}{*}{$\Delta R^{2}$} \\
\hline & & $\mathrm{B}$ & SE & & & & & & & \\
\hline \multirow[t]{10}{*}{ Organisational Commitment } & & & & & & & $22.08^{*}$ & 0.58 & 0.34 & 0.32 \\
\hline & (Constant) & 31.60 & 0.82 & & 38.36 & 0.00 & & & & \\
\hline & Work Relations & -0.07 & 0.04 & -0.11 & -1.60 & 0.11 & & & & \\
\hline & Work-Life Balance & 0.07 & 0.05 & 0.08 & 1.41 & 0.16 & & & & \\
\hline & Overload & -0.07 & 0.07 & -0.07 & -1.07 & 0.27 & & & & \\
\hline & Job Security & -0.08 & 0.06 & -0.08 & -1.52 & 0.13 & & & & \\
\hline & Control & -0.24 & 0.07 & -0.24 & -3.33 & $0.00^{*}$ & & & & \\
\hline & Resources & -0.18 & 0.08 & -0.15 & -2.32 & $0.02^{*}$ & & & & \\
\hline & Job Aspects & -0.05 & 0.04 & -0.07 & -1.21 & 0.23 & & & & \\
\hline & Pay & -0.19 & 0.12 & -0.07 & -1.52 & 0.13 & & & & \\
\hline \multirow[t]{10}{*}{ Individual Commitment } & & & & & & & $12.39^{*}$ & 0.47 & 0.22 & 0.21 \\
\hline & (Constant) & 24.08 & 0.68 & & 35.43 & 0.00 & & & & \\
\hline & Work Relations & 0.03 & 0.03 & 0.05 & 0.69 & 0.49 & & & & \\
\hline & Work-Life Balance & 0.12 & 0.04 & 0.17 & 2.90 & $0.00^{*}$ & & & & \\
\hline & Overload & -0.13 & 0.06 & -0.16 & -2.42 & $0.02^{*}$ & & & & \\
\hline & Job Security & 0.03 & 0.05 & 0.04 & 0.71 & 0.48 & & & & \\
\hline & Control & -0.16 & 0.06 & -0.21 & -2.72 & $0.01^{\star}$ & & & & \\
\hline & Resources & -0.13 & 0.07 & -0.14 & -1.92 & 0.06 & & & & \\
\hline & Job Aspects & -0.09 & 0.04 & -0.16 & -2.46 & $0.01^{*}$ & & & & \\
\hline & Pay & -0.20 & 0.10 & -0.10 & -1.96 & $0.05^{\star}$ & & & & \\
\hline
\end{tabular}

$* p<0.05$ 
$16 \%$ score at the low end, and another 16\% score at the high end. Validity is still to be completed (Cartwright \& Cooper, 2002).

Reliability is based on the Guttman split-half coefficient. All but two factors returned coefficients in excess of 0.70 , ranging from 0.60 to 0.91 (Cartwright \& Cooper, 2002). Johnson and Cooper (2003) found that the psychological well-being subscale has good convergent validity with an existing measure of psychiatric disorders, the General Health Questionnaire (GHQ - 12) (Goldberg \& Williams, 1988). Tytherleigh (2003) used the ASSET as an outcome measure of job satisfaction in a nationwide study of occupational stress levels in 14 English higher education institutions. Cronbach alphas were determined for each of the questions of the five ASSET subscales. The values ranged from 0.64 to 0.94 , which showed good reliability.

A biographical questionnaire was designed and used to gather information on various aspects of the population, for example, gender, marital status, language, and education.

\section{Research procedure}

The first author administered hard copies of the questionnaires to participants in theinstitution. The copies of the questionnaires were collected directly after they had been completed anonymously by the participants. The fieldworkers explained to the participants that the information in the completed questionnaires would be treated confidentially.

\section{Statistical analysis}

The statistical analysis was carried out with the help of the SPSS program (SPSS Inc., 2003). Descriptive statistics (for example, means, standard deviations, skewness and kurtosis) were used to analyse the data. Factor analyses were not carried out for the purposes of this study for two reasons. Firstly, the validity of the ASSET has been researched in previous studies both in the United Kingdom (Tytherleigh, 2003) and in South Africa (Barkhuizen \& Rothmann, 2008; Coetzee \& Rothmann, 2005).

Secondly, the authors were interested in comparing the findings on the current factors with a national norm. Cronbach alpha coefficients were used to assess the reliability (that is, internal consistency) of the measuring instruments (Clark \& Watson, 1995).

Standard multiple regression analysis was carried out to assess the contribution of the independent variables (Work Relations, Work-Life Balance, Overload, Job Security, Control, Resources, Job Aspects and Pay) to dependent variables (Physical Ill Health, Psychological Ill Health, Organisational Commitment and Individual Commitment). According to Tabachnick and Fidell (2001), the correlation between an independent variable and a dependent variable reflects variance shared with the dependent variable.

\section{RESULTS}

The descriptive statistics, alpha coefficients and correlations of the factors of the ASSET subscales, namely, Organisational Stressors (Work Relations, Work-Life Balance, Overload, Job Security, Control, Resources, Job Aspects and Pay), Ill Health (Physical and Psychological) and Organisational Commitment (Commitment of the Individual to the Organisation and Commitment of the Organisation to the Individual) are given in Table 2.

From the results in Table 2, it is clear that there is acceptable internal consistency in the ASSET dimensions of Work Relations, Work-Life Balance, Overload and Control, as well as the Physical and Psychological Health dimensions, and Organisational and Individual Commitment. All of these dimensions demonstrate acceptable Cronbach alpha coefficients above the 0.70 guideline provided by Nunnally and Bernstein (1994). The other three dimensions, namely, Job Security, Resources and Job Aspects display alphas below the 0.70 guideline.

Table 2 shows that the sten scores of Job Security and Control were higher than the mean of 5.5. Physical and Psychological Ill Health were also higher than the mean, while individual commitment was somewhat lower than the mean.

Practically significant (positive, medium effect) correlations exist between Psychological Ill Health and all the occupational stressors, except Work-Life Balance and Pay. No practically significant correlations were found between any of the occupational stressors and Physical Ill Health. Physical and Psychological Ill Health show a positive correlation (practically significant, large effect).

As far as commitment is concerned, negative correlations were found with all of the occupational stressors. Organisational Commitment showed practically significant (negative, medium effect) correlations with all the occupational stressors, except Work-life Balance and Pay (negative, statistically significant), and Control (negative, large effect). Individual Commitment showed (negative, practically significant) correlations with Work Relations, Control, Resources and Job Aspects. Finally, Organisational Commitment showed a practically significant (negative, medium effect) correlation with Psychological Ill Health.

In order to determine whether organisational stressors predict Physical and Psychological Ill Health as well as Organisational and Individual Commitment (as measured by the ASSET), a series of standard multiple regression analyses were conducted. The results of the multiple regression analysis with occupational stressors (as measured by the ASSET) and Physical and Psychological Ill Health as dependent variables are reflected in Table 3.

Table 3 shows that $15 \%$ of the variance in Physical Ill Health is explained by the occupational stressors. It is clear that stress about Job Security was the only statistically significant predictor $(p<0.05)$. Therefore, stress because of (a lack of) job security contributes statistically significantly to higher levels of physical ill health. Table 3 also shows that $26 \%$ of the variance in Psychological Ill Health is predicted by the occupational stressors. Stress because of Overload, Job Security and Job Aspects are statistically significant predictors of individuals' Psychological Ill Health. These results partially support Hypothesis 1.

The results of the standard multiple regression analysis with Organisational and Individual Commitment as dependent variables and occupational stressors (as measured by the ASSET) are reflected in Table 4.

Table 4 shows that $34 \%$ of the variance in Organisational Commitment to the individual is explained by occupational stressors. It is clear that Control and Resources were the only statistically significant predictors $(p<0.05)$. Therefore, stress because of a lack of control in a job, as well as stress because of a lack of resources contributes statistically significantly to lower levels of perceived commitment of the organisational to the individual. Table 4 also shows that $22 \%$ of the variance in Individual Commitment to the organisation is predicted by occupational stressors. Work-life Balance, Overload, Control, Pay and Job Aspects are statistically significant predictors of low Individual Commitment to the organisation. These results partially support Hypothesis 2.

\section{DISCUSSION}

The aim of this study was to investigate the relationship between perceived organisational stressors and the levels of 
commitment and ill health of staff of a university of technology. The results showed that job security and control (lack of autonomy) were the most significant stressors in the total organisation. It can be concluded that an array of occupational stressors are related to the staff's psychological ill health and organisational and individual commitment. Furthermore, it was found that staff members' experiences of specific occupational stressors led to lower levels of organisational and individual commitment as well as to higher levels of physical and psychological ill health.

The results of this study should not be seen in isolation but should be interpreted against the background of the current higher education system in South Africa. The current restructuring of the higher education sector with consequences such as financial predicaments for institutions and increased demands for access accompanied with growing student numbers, insecurity about the future of institutions and subsequently staff members' job security as well as rapid changes in various spheres of the institutions are creating emotional turmoil and stress for academic and support staff (Clarke \& Koonce, 1995; Hellriegel et al., 2001; Mestry, 1999; Tennant, 2001). Apart from executing their normal duties (which in itself can lead to the experience of stress), staff have also been confronted with stresses associated with the transformation of the broader South African society as a whole. Seldin (1991) also mentions that this situation is bound to continue, and that staff of higher education institutions in South Africa will, in future, be confronted with increasing levels of stress.

As far as the psychological ill health of staff at the institution under study is concerned, all the occupational stressors except pay and work-life balance seem to be related. This confirms findings by Kahn and Byosiere (1992) that high levels of occupational stress, if left unchecked, could lead to psychological ill health. Hothopf and Wesseley (1997) also explain that psychological ill health could manifest as burnout, alcohol abuse, unexplained physical symptoms, absenteeism, chronic fatigue and increased accidents at work. The work relationships and accompanying social support experienced by staff of this university, aspects of the job (for example, time pressures, learner discipline, system of promotion, role overload), lack of autonomy, overload, and lack of resources seem to be the major stressors related to psychological ill health. This can be better understood if one considers the history of the institution and the changes it has undergone over the past few years, with unprecedented growth in student numbers without a proportional increase in staff. Furthermore, the changes at institutional level from a technikon to a university of technology have had a direct impact on the nature of the work itself.

As far as work relationships are concerned, the geographical distribution of the different campuses needs consideration. Staff from various campuses have to lecture the same material, administer tests on the same date and time and co-ordinate academic activities in order to ensure equality in teaching and learning across campuses. The communication that accompanies this co-ordination of activities is normally done by telephone or e-mail with very limited opportunities to communicate face to face. This in itself could explain why interpersonal relationships between colleagues and managers are sometimes strained and contribute to the experience of stress.

With reference to aspects of the job, the increased student numbers, cultural differences between a predominantly White staff and predominantly Black student corps, as well as low pass rates of students from predominantly disadvantaged backgrounds could be seen as contributing factors. The change from a technikon to a university also brought a different focus to the institution with subsequent pressure on staff to not only lecture but also to engage more intensively in research and community service. Also, the fact that the name has changed to 'university' in itself places the institution in the domain of traditional universities, most of which have a competitive advantage, at least in some areas.

The control aspect that has been identified could be linked to the formal and sometimes rigid type of management system in the institution. Although necessary to ensure quality and legitimacy of qualifications, this could be a negative aspect as far as staff are concerned. The lack of resources also needs mentioning. In this regard, there are huge discrepancies between infrastructure and available resources between campuses. This is a result of the history in the institution and, whilst not always reasonable, it can be expected that staff will compare the different campuses in terms of available resources within the institution. These perceived discrepancies between available resources could lead to the experience of stress as all staff members are expected to perform on the same level.

The relationship between occupational stress and physical ill health seems to be slightly less clear. Only limited relationships could be established in this study between the occupational stressors and physical ill health. Of importance, however is to note that there is ample evidence in the literature that psychological ill health leads to physical ill health (Siu, 2002; Winefield et al., 2002). In this regard, the significant relationship shown in this study between physical and psychological ill health confirms this notion, but could also be a precursor of the development of future physical ill health problems in staff of the university. This aspect should be a cause for concern as stress-related health problems that might develop in future could lead to increased health benefit costs to the institution (Everley \& Fieldman, 1991), as well as to staff. Furthermore, it has been shown that individuals who experience stress make errors more often, are absent from work more often and need to be replaced more often (Carstens, 1989; Jacobs, 2001; Quick et al., 1992), all of which could lead to increased expenditure for the institution.

The results also indicate a negative relationship between the various occupational stressors and organisational commitment. This implies that the presence of some or all of these occupational stressors will erode the organisational commitment relationship. It can thus be expected that the experience of these occupational stressors will negatively affect staff's identification with and involvement in the organisation and its goals, as well as their willingness to participate in organisational activities and decision-making (Allen \& Meyer, 1990; Chow, 1994; Robbins, 1998). Work relations, the availability of resources and the amount of autonomy that staff have are aspects that seem to be especially relevant to the levels of stress they experience. In this regard, the aspects mentioned earlier as well as the formal type of management system with accompanying 'red tape' and 'lack of delegation' of authority could be contributing factors. Individual commitment, on the other hand, is significantly negatively related to a group of more specific occupational stressors already discussed, namely, work relations, control, resources and aspects of the job.

Multiple regression analysis showed that $34 \%$ of the variance in organisational commitment of staff at this university is predicted by the occupational stressors. It further revealed that control and resources were the only statistically significant predictors of organisational commitment. This implies that staff of this institution will exhibit lower levels of organisational commitment (that is, feel that the organisation is not committed to them) when they experience stress as a result of lacking autonomy and if they lack the necessary resources to execute their duties. As far as individual commitment is concerned, similar analysis indicates that $22 \%$ of the variance in individual commitment is predicted by occupational stressors. The stressors of work-life balance, overload, control, job aspects and pay were the only statistically significant predictors of individual commitment. From these results, it is evident that staff will show lower levels of individual commitment (the 
extent to which they feel committed to the organisation) when they experience stress as a result of balancing the demands of their work and personal lives, an unreasonably high workload, lacking autonomy in the workplace, job-specific aspects (i.e. time pressures, learner discipline, system of promotion and role overload), and the remuneration they receive.

In relation to physical ill health, multiple regression analysis showed that $15 \%$ of the variance in physical ill health is predicted by occupational stressors. Job security was found to be the only statistically significant $(\mathrm{p}<0.05)$ stressor. This indicates that staff will experience higher levels of physical illness as a result of the stress associated with losing one's job, changes in the workplace or redundancy. A similar analysis of the psychological health dimension showed that $26 \%$ of the variance in psychological ill health was predicted by the overload, job security and job aspects stressors. This implies that staff of this institution will experience higher levels of psychological ill health as result of stress associated with high workload, the prospect of being unemployed and job-specific aspects. Based on the above findings both Hypothesis 1 and Hypothesis 2 are partially adopted.

A limitation of this study is its reliance solely on self-report measures. According to Schaufeli et al. (1993), the exclusive use of self-report measures in validation studies increases the likelihood that at least part of the shared variances between measures can be attributed to method variance. Another limitation is the sampling method and sample size. The total population of academic and support staff at the institution was targeted, but a response rate of $21.88 \%$ was obtained. Although the sampling method and size make it impossible to generalise the findings to the total population of employees in the institution, the findings still respesent important insights regarding occupational stress and the outcomes thereof in a university of technology.

\section{Recommendations}

The use of the ASSET is recommended to assess the levels of stress, organisational commitment and health of staff in higher education institutions in South Africa. This is another step towards the validation of the ASSET as an organisational stress-screening tool. Based on this and previous studies, it is recommended that further reliability and validity research be undertaken in other higher education institutions in South Africa. This could lead to the establishment of sector-specific norms and could also provide a basis for comparison within the sector.

Staff's cognitive appraisal of occupational stressors and the resultant effect it has on their levels of commitment as well as health is a reason for concern in South African higher education. It is recommended that the ASSET be used to identify institution-specific occupational stressors and that interventions be developed to address these stressors at the individual and institutional level. At the institutional level, interventions should be targeted at eliminating, reducing or changing the perceived stressors. These could include facilitating positive work relationships, job redesign to ensure that staff has equitable but manageable workloads, delegation of authority, providing adequate resources and communication as well as ensuring that the reward system is equitable and fair. On the individual level, interventions should aim to assist employees to develop skills in dealing with stress more effectively, finding a balance between work and private life demands, and continuous development of staff in order to ensure that they remain competitive in an ever-changing world of work. Other interventions could include the development of coping strategies especially with regard to dealing with change and transformation, as well as encouraging individuals to engage in physical activity and healthy lifestyles.

\section{AUTHOR'S NOTE}

The material described in this article is based upon work supported by the National Research Foundation under Grant number 2053344.

\section{REFERENCES}

Abouserie, R. (1996). Stress, coping strategies and job satisfaction in university academic staff. Educational Psychology, 16(1), 49-57.

Allen, N., \& Meyer, J. (1990). The measurement and antecedents of affective, continuance and normative commitment to the organization. Journal of Occupational Psychology, 63, 1-18.

Altbach, P.G. (1996). The international academic profession. Portraits from fourteen countries. Princeton: Carnegie Foundation for the Academic Profession.

Anderson, G.S., Litzenberger, R., \& Plecas, D.B. (2002). Physical evidence of police officer stress. Policing: An International Journal of Police Strategies \& Management, 25, 399-420.

Association for University Teachers. (1990). Goodwill under stress: Morale in UK universities. London: Association of University Teachers.

Barkhuizen, N., \& Rothmann, S. (2008). Occupational stress of academic staff in South African higher education institutions. SA Journal of Psychology, 28, 321-336.

Bhagat, R.S., Ford, D.L., O'Driscoll, M.P., Frey, L., Babakus, E., \& Mahanyele, M. (2001). Do South African managers cope differently from American managers? A cross-cultural investigation. International Journal of Intercultural Relations, 25, 301-313.

Blackmore, J. (2002). Globalisation and the restructuring of higher education for new knowledge economies: New dangers or old habits troubling gender equity work in universities. Higher Education Quarterly, 56, 419-441.

Bourbonnais, R., Comeau, M., \& Vezina, M. (1999). Job strain and evolution of mental health among nurses. Journal of Occupational Health Psychology, 4, 95-107.

Carstens, L. (1989). Die ontwikkeling en implementering van ' $n$ stresbeheerprogram vir middelvlakbestuurders in ' $n$ diensorganisasie. Unpublished doctoral thesis. University of the Free State, Bloemfontein, South Africa.

Cartwright, S., \& Cooper, C.L. (2002). ASSET: An Organizational Stress Screening Tool - The Management Guide. Manchester: RCL Ltd.

Chow, I.H. (1994). Organisational commitment and career development of Chinese managers in Hong Kong and Taiwan. International Journal of Career Management, 6(4), 3-9.

Clark, J., \& Koonce, R. (1995). Engaging organisational survivors. Training and Development, 49(8), 22-30.

Clark, L.A., \& Watson, D. (1995). Constructing validity: Basic issues in objective scale development. Psychological Assessment, 7, 309-319.

Coetzee, S.E., \& Rothmann, S. (2005). Occupational stress in a higher education institution in South Africa. South African Journal of Industrial Psychology, 31(1), 47-54.

Curri, G. (2002). Reality versus perception: Restructuring tertiary education and institutional organizational change - A case study. Higher Education, 44(1), 133-151.

Daniels, K., \& Guppy, A. (1994). Occupational stress, social support, job control, and psychological well-being. Human Relations, 47, 1523-1544.

De Jonge, J., Reuvers, M.M., Houtman, I.L., Bongers, P.M., \& Kompier, M.A. (2000). Linear and nonlinear relations between psychosocial job characteristics, subjective outcomes, and sickness absence: Baseline results from SMASH. Study on musculoskeletal disorders, absenteeism, stress, and health. Journal of Occupational Health Psychology, 5, 256-268.

Demerouti, E., Bakker, A.B., Nachreiner, F., \& Schaufeli, W.B. (2000). A model of burnout and life satisfaction amongst nurses. Journal of Advanced Nursing, 32, 454-464. 
Dollard, M.F., Winefield, A.H., \& Winefield, H.R. (2003). Occupational stress in the service professions. New York: Taylor \& Francis.

Everley, G.S., \& Fieldman, R.H. (1991). Occupational health promotion. New York: Wiley.

Faragher, E.B., Cooper, C.L., \& Cartwright, S. (2004). A shortened stress evaluation tool (ASSET). Stress and Health, 20, 189201.

Finkelstein, M. (2003). The morphing of the American academic profession: Every societal transformation in the role of higher education has brought in its wake a concomitant transformation in the faculty role. Liberal Education, 89(4), 6-14.

Glass, D., \& McKnight, J.D. (1996). Perceived control, depressive symptomatology, and professional burnout: A review of the evidence. Psychology and Health, 11, 23-48.

Goldberg, D.P., \& Williams, P. (1988). A user's guide to the GHQ. London: NFER, Nelson.

Grzywacz, J.G. (2000). Work-family spillover and health during midlife: Is managing conflict everything? American Journal of Health Promotion, 14, 236-243.

Gumport, P.J. (2000). Academic restructuring: Organizational change and institutional imperatives. Higher Education, 39(1), 67-91.

Hellriegel, D., Slocum, J.W., \& Woodman, R.W. (2001) Organizational behavior. (9th edn.). Cincinnati: South-Western College Publishing.

Hothopf, M., \& Wesseley, S. (1997). Stress in the workplace: Unfinished business. Journal of Psychosomatic Research, 43(1), $1-6$.

Houghton, P. (2001). Finding allies: Sustaining teachers' health and well-being. Phi Delta Kappan, 82, 706-712.

Industrial Society. (2001). Managing best practice: Research Summaries No. 83: Occupational Stress. London: Industrial Society.

Ivancevich, J.M., \& Matteson, M.T. (1996). Organizational behavior and management. (4th edn.). Boston: Irwin.

Jacobs, Y. (2001). Die voorspelling van die effektiewe hantering van werkstres by bestuurspersoneel met behulp van persoonlikheidsveranderlikes. Unpublished master's dissertation, University of the Free State, Bloemfontein, South Africa.

Jamal, M. (1999). Job stress and employee wellbeing: A crosscultural empirical study. Stress Medicine, 15, 153-158.

Johansson, G. (1989). Job demands and stress reactions in repetitive and uneventful monotony at work. International Journal of Health Services, 192, 365-377.

Johnson, S., \& Cooper, C.L. (2003). The construct validity of the ASSET stress measure. Stress and Health, 19, 181-185.

Jones, F., \& Bright, J. (2001). Stress: Myth, theory and research. London: Pearson Education.

Kahn, R.L., \& Byosiere, P. (1992). Stress in organizations. In M.D. Dunnette (Ed.), Handbook of industrial and organisational psychology (pp. 571-648). Chicago: Rand McNally.

Khosa, M.M. (1996). Leaders or followers? Transforming South African universities. Indicator South Africa, 13(4), 73-77.

Kinman, G. (2001). Pressure points: A review of stressors and strains in UK academics. Educational Psychology, 21, 474492.

Kraak, A. (2004). Discursive tensions in South African Higher Education, 1990 to 2002. Journal of Studies in International Education, 8, 244-281.

Kreitner, R., \& Kinicki, A. (1995). Organisational behavior. (3rd edn.). Chicago: Irwin.

Kyriacou, C. (2001). Teacher stress: Directions for future research. Educational Review, 53(1), 27-36.

Lacy, F.J., \& Sheehan, B.A. (1997). Job satisfaction among academic staff: An international perspective. Higher Education, 34, 305-322.

Leong, C.S., Furnham, A.E., \& Cooper, C.L. (1996). The moderating effect of organizational commitment on the occupational stress outcome relationship. Human Relations, $49,1345-1363$
Lu, L. (1999). Work, motivation, job stress and employees' wellbeing. Journal of Applied Management Studies, 8, 61-72.

Mack, D.A., Nelson, D.L., \& Quick, J.C. (1998). The stress of organisational change: A dynamic process model. Applied Psychology: An International Review, 47, 219-232.

Makin, P.J., Cooper, C.L., \& Cox, C. (2003). Organisations and the psychological contract: Managing people at work. Leicester: British Psychological Society Books.

Manicas, P. (1998). The radical restructuring of higher education. Futures, 30, 651-656.

Marchand, A., Demers, A., Durand, P., \& Simard, M. (2003). The moderating effect of alcohol intake on the relationship between work strains and psychological distress. Journal of Studies on Alcohol, 64, 419-427.

McDonough, P. (2000). Job insecurity and health. International Journal of Health Services, 30, 453-476.

Mestry, R. (1999). The role of principals in the management of stress and burnout. Education Practice, 3, 19-23.

Meyer, J.P., \& Allen, N.J. (1991). A three-component conceptualization of organizational commitment. Human Resource Management Review, 1, 61-89.

Mok, K.H. (2003). Globalizations and higher education restructuring in Hong Kong, Taiwan and Mainland China. Higher Education Research E Development, 22(2), 117-129.

Mostert, F.F., Rothmann, S., Mostert, K., \& Nell, K. (2008). Outcomes of occupational stress in a higher education insitution. South African Business Review, 12(3), 102-127.

Mowday, R.T., Porter, L.W., \& Steers, R.M. (1982). Employeeorganizational linkages: The psychology of commitment, absenteeism and turnover. New York: Academic Press.

Newstrom, J.W., \& Davis, K. (2002). Organizational behavior: Human behavior at work. (11th edn.). New York: McGrawHill.

Nunnally, J.C., \& Bernstein, I.H. (1994). Psychometric theory. (3rd edn.). New York: McGraw-Hill.

O’Driscoll, M.P., \& Cooper, C.L. (1996). Sources and management of excessive job stress and burnout. In P. Warr (Ed.) Psychology at work. (4th edn.). London: Penguin.

Pilkington, A., Mulholland, R.E., \& Cowie, H.A. (2001). Baseline measurements for the evaluation of the work-related stress campaign. CRR 322/2001. HSE Contract Research Report. Sudbury: HSE Books.

Pillay, K., \& Claase-Schutte, C. (2003, July). Private security officers as victims of trauma and stress: The South African experience and initiatives to manage it. Paper presented at the World Society of Victimology, XIth International Symposium on Victimology, Stellenbosch, South Africa.

Pugliesi, K.A. (1999). The consequences of emotional labor: Effects on work stress, job satisfaction and well-being. Motivation and Emotion, 23(2), 125-154.

Quick, J.C., Murphy, L.R., \& Hurrel, J.J. (1992). Stress and wellbeing at work. Assessments and interventions for occupational mental health. Washington, DC: American Psychological Association.

Quick, J.C., Quick, J.D., Nelson, D.L., \& Hurrell, J.J. (1997) Preventative stress management in organizations. Washington, DC: American Psychological Association.

Robbins, S.P. (1998). Organizational behavior: Concepts, controversies, and applications. (8th edn.). Englewood Cliffs: Prentice-Hall.

Romanov, K., Appelberg, K., Honkasalo, M.L., \& Koskenvuo, M. (1996). Recent interpersonal conflict at work and psychiatric morbidity: A prospective study of 15,530 employees aged 24 - 64. Journal of Psychosomatic Research, 40, 169-176.

Rothmann, S., \& Essenko, N. (2007). Burnout of support staff in a higher education institution in the North West Province. South African Journal of Psychology, 37, 135-152.

Schafer, W. (2000). Stress management for wellness. New York Harcourt College Publishers.

Schaufeli, W.B., Enzmann, D., \& Girault, N. (1993). The measurement of burnout: A review. In W.B. Schaufeli, C. Maslach \& T. Marek (Eds.), Professional burnout: Recent developments in theory and research (pp. 199-215). Washington, DC: Taylor \& Francis. 
Schaufeli, W.B., Maslach, C., \& Marek, T. (Eds.). (1993). Professional burnout: Recent developments in theory and research. Washington, DC: Taylor \& Francis.

Seijts, G.H., \& O'Farrell, G. (2003). Engage the heart: Appealing to the emotions facilitates change. Ivey Business Journal, 67(3), 1-5.

Seldin, P. (1991). Reducing stress on campus. Planning for Higher Education, 9(4), 14-20.

Shirom, A., Westman, M., \& Melamed, S. (1999). The effects of pay systems on blue-collar employees' emotional distress: The mediating effects of objective and subjective work monotony. Human Relations, 52, 1077-1097.

Siu, O.L. (2002). Occupational stressors and well-being among Chinese employees: The role of organizational commitment. Applied Psychology: An International Review, 5, 527-544.

SPSS Inc. (2003). SPSS 12.0 for Windows. Chicago: SPSS Inc..

Spurgeon, A., Harrington, M.J., \& Cooper, C.L. (1997). Health and safety problems associated with long working hours: A review of the current position. Occupational and Environmental Medicine, 54, 367-375.

Suliman, A.M., \& Iles, P.A. (2000a). Is continuance commitment beneficial to organizations? Commitment-performance relationship: A new look. Journal of Managerial Psychology, $15,407-426$.

Suliman, A.M., \& Iles, P.A. (2000b). The multi-dimensional nature of organizational commitment in a non-western context. Journal of Managerial Psychology, 19, 1-7.

Tabachnick, B.G., \& Fidell, L.S. (2001). Using multivariate statistics. (4th edn.). Boston: Allyn \& Bacon.

Tennant, C. (2001). Work-related stress and depressive disorders. Journal of Psychosomatic Research, 51, 697-704.

Tepper, B.J. (2000). Consequences of abusive supervision. Academy of Management Journal, 4, 178-190.

Tucker, L.R., \& Lewis, C. (1973). A reliability coefficient for maximum likelihood factor analysis. Psychometrica, 38, $1-10$.
Tytherleigh, M.Y. (2003). What employers may learn from English higher education institutions: A fortigenic approach to occupational stress. SA Journal of Industrial Psychology, 29(4), 101-106.

Van der Doef, M., Maes, S., \& Diekstra, R. (2000). An examination of the job demand-control-support model with various occupational strain indicators. Anxiety, Stress and Coping: An International Journal, 13, 165-185.

Van Zyl, Y., \& Buitendach, J.H. (2004, March). Occupational stress, job satisfaction and organisational commitment of educators on senior level in the Sedibeng West district Vanderbijlpark. Poster presented at the 2nd South African Work Wellness conference, Potchefstroom, South Africa.

Varca, P.E. (1999). Work stress and customer service delivery. The Journal of Service Marketing, 13, 229-241.

Voydanoff, P., \& Donnelly, B.W. (1999). Multiple roles and psychological distress: The intersection of the paid worker, spouse, and parent roles with the role of the adult child. Journal of Marriage and the Family, 61, 725-738.

Weinberg, A., \& Cooper, C. (2007). Surviving the workplace: A guide to emotional well-being. London: Thomson.

Wevers, N.E.J., \& Steyn, G.M. (2002). Opvoeders se persepsies van hulle werkmotivering: 'n Kwalitatiewe studie. South African Journal of Education, 22, 205-212.

Winefield, A.H., Gillespie, N., Stough, C., Dua, J., \& Hapuararchchi, J. (2002). Occupational stress in Australian universities: A national survey. Melbourne: National Tertiary Education Union.

Wood, F., \& Meek, L. (2002). Over-received and underfunded? The evolving policy context of Australian higher education research and development. Journal of Higher Education Policy and Management, 24, 7-25.

Woordard, C. (1997). Experts see Russian higher education becoming diverse and decentralized. The Chronicle of Higher Education, 44(13), A43-45. 